\title{
Pengkonsepsian dan Pembinaan Instrumen Kualiti Kehidupan Kerja Guru
}

\author{
Nordin Abd Razak, Lei Mee Thien * \\ School of Educational Studies, Universiti Sains Malaysia, 11800 Minden, Penang, Malaysia
}

*Corresponding author: thienleimee@usm.my

\begin{abstract}
This study aims to conceptualise and develop an instrument measures teacher quality of work life based on four main theories, namely (1) socio-technical systems theory, (2) two factor Herzberg theory, (3) organisation management theory, including structure and human relationship theories, and (4) psychological interactive theory. Based on these theories, the construct of teacher quality of work life has been conceptualised to have four main dimensions, namely (1) psychological need, (2) social need, (3) political need, and (4) economical need. A total of 1,080 school teachers were selected from 30 primary schools in Penang and Kedah and measured with more 44 items. Exploratory factor analysis and confirmatory factor analysis were performed to examine the reliability and validity of the instrument measures teacher quality of work life using IBM SPSS 20.0 and AMOS 20.0 computer software. Findings revealed that 12 out of 32 items need to be excluded because of its poor psychometric properties. The remaining 20 items that measure these four main dimensions of teacher quality of work life have shown satisfactory construct validity with the values of goodness-of-fit indices lie within the proposed acceptable range. Political need contributed the highest variance to explain teachers' quality of work life compared to other dimensions. Implications and suggestions for future studies were presented.
\end{abstract}

Keywords: Teacher quality of work life, instrument development, reliability, construct validity

\begin{abstract}
Abstrak
Kajian ini bertujuan untuk mengkonsepsi dan membina instrumen mengukur kualiti kehidupan kerja guru berdasarkan empat teori, iaitu (1) teori sistem sosio-teknikal, (2) teori dua faktor Herzberg, (3) teori pengurusan organisasi yang merangkumi (a) teori struktur dan (b) teori perhubungan manusia, dan (4) teori psikologikal interaktif. Bersandarkan kepada teori-teori ini, kualiti kehidupan kerja guru dikonsepsikan mempunyai empat dimensi utama, iaitu (a) keperluan psikologi, (b) keperluan sosial, (c) keperluan politik, dan (d) keperluan ekonomi. Sejumlah 1,080 orang guru sekolah daripada 90 buah sekolah rendah di Pulau Pinang dan Kedah telah dipilih sebagai sampel kajian. Kebolehpercayaan dan kesahan instrumen bagi mengukur konstruk kualiti kehidupan kerja guru telah dilaksanakan dengan analisis faktor eksploratori dan analisis faktor konfirmatori menggunakan perisian komputer IBM SPSS 20.0 and AMOS 20.0. Dapatan menunjukkan 12 item daripada 32 item perlu digugurkan kerana mempunyai ciri-ciri psikometrik item yang lemah. Sebanyak 20 items yang mengukur empat dimensi utama didapati memenuhi kriteria untuk kesahan konstruk dan nilai 'goodness-of-fit' indeks berada dalam linkungan yang dicadangkan. Keperluan politik menyumbangkan varians yang tertinggi dalam konstruk kualiti kehidupan guru berbanding dengan dimensi lain. Implikasi dan cadangan kajian masa depan turut dibincangkan.
\end{abstract}

Kata kunci: Kualiti kerja kehidupan guru, pembinaan instrumen, kepercayaan, kesahan konstruk

(C) 2017 Penerbit UTM Press. All rights reserved

\subsection{PENGENALAN}

Mengajar di sekolah pada hari ini merupakan satu proses yang dinamik. Pelbagai perubahan yang berlaku secara berterusan dalam pelbagai aspek seperti pedagogi, teori pembelajaran, kurikulum, dan matlamat-matlamat pendidikan menyebabkan guru-guru menghadapi pelbagai cabaran (Louis \& Smith, 1990). Guru-guru memerlukan pengetahuan dan kemahiran untuk mengendali pengajaran dan pembelajaran dalam bilik darjah dengan berkesan di samping menangani pelajar dari pelbagai latar belakang dan kebolehan, tahap motivasi, dan tingkah laku yang mungkin sukar untuk dikawal selia (Louis \& Smith, 1990). Maka, adalah menjadi tugas utama pentadbir sekolah untuk mengekalkan guru-guru yang baik dan berkualiti sebagai sumber manusia yang bernilai (Darling-Hammond, 2000). Menurut Kajian Antarabangsa Pengajaran dan Pembelajaran 2013 (TALIS), persekitaran sekolah sebagai tempat guru melaksanakan tanggungjawab memberi impak terhadap kualiti pengajaran guru (Kementerian Pendidikan Malaysia, 2016). Oleh itu, sekolah perlu berperanan untuk menyediakan persekitaran kerja yang lebih baik dan efisien bagi meningkatkan kualiti kehidupan kerja guru. Menurut Elizur dan Shye (2011) ketidakpuasan terhadap kualiti kehidupan kerja boleh mempengaruhi kebanyakan pekerja tanpa mengira status atau kedudukan dalam sesebuah organisasi.

Terdapat pelbagai perspektif pakar atau penyelidik tentang konsep dan definisi Kualiti Kehidupan Kerja. Istilah ini pertama kali diperkenalkan dalam Persidangan Antarabangsa Kualiti Kehidupan Kerja Kali Pertama di Arden House pada tahun 1972 (Hian \& Einstein, 1990) yang kemudiannya menggerakkan kajian-kajian berkaitan dengan konstruk ini. Sesuatu yang pasti ialah kualiti kehidupan kerja telah dikonsepsikan dengan pelbagai pendekatan bergantung kepada situasi dan peranan individu dalam sesuatu organisasi yang tertentu 
(Edwards, Van Laar, Easton, \& Kinman, 2009).Contohnya, dalam konteks teknologi maklumat, kualiti kehidupan kerja dirujuk sebagai keberkesanan persekitaran yang dapat membentuk kesejahteraan dan kepuasan dalam kalangan pekerja dalam organisasi (Rethinam \& Ismail, 2007). Selain itu, kualiti kehidupan kerja juga dikonsepsikan sebagai satu inovasi dalam memastikan kepuasan pekerja yang boleh menyumbang kepada keberkesanan organisasi dan produktiviti (Mohanraj \& Ramesh, 2010) Holt (1998) menghuraikan kualiti kehidupan kerja sebagai satu keadaan untuk menyediakan persekitaran kerja yang kondusif yang dapat memenuhi keperluan pekerja sehingga mereka bermotivasi untuk melaksanakan tugas dan mencapai kepuasan dalam kerja yang dilakukan. Fitzsimmons (2002) pula mendefinisikan kualiti kehidupan kerja sebagai satu keadaan atau kriteria kerja yang dapat membina motivasi, semangat, kualiti dan kepuasan kerja para pekerjanya. Pandangan oleh Holt (1998) dan Fitzsimmons (2002) bersesuaian dengan pendapat Walton (1975) yang mengatakan bahawa kualiti kehidupan kerja merupakan satu proses iaitu cara sesebuah organisasi memberi respons terhadap keperluan pekerja dalam usaha membina rasa kekitaan, dan autonomi dalam membuat keputusan kehidupan kerja mereka. Secara umumnya dapat dikatakan bahawa kualiti kehidupan kerja adalah satu konstruk yang komprehensif bertujuan untuk membangunkan diri individu (pekerja) yang melibatkan kesejahteraan pekerja seperti memberikan pengalaman kerja yang bermanfaat dan menyeronokkan, memenuhi keperluan peribadi pekerja sebagai individu serta mengelakkan tekanan dan kesan-kesan negatif akibat kerja. Banyak kajian telah membuktikan bahawa kualiti kehidupan kerja mempunyai impak yang signifikan terhadap respon tingkah laku pekerja seperti kepuasan kerja, penglibatan kerja, usaha kerja, prestasi kerja, hasrat untuk berhenti, perubahan organisasi dan pengasingan diri (Arthy \& Nandhini, 2016; Phan \& Vo, 2016; Yavari, Amirtash, \& Tondnevis, 2009).

Kualiti kehidupan kerja dikenalpasti sebagai satu konstruk yang bersifat multidimensi mengikut konteks kajian (Morin \& Morin, 2003) serta dikonsepsikan dengan menggunakan pelbagai pendekatan mengikut pemikiran dan pemahaman penyelidik tentang individu, pekerjaan dan organisasi yang dianggotainya (Cummings \& Malloy, 1977; Yousuf, 1996). Sebagai contoh ialah model kualiti kehidupan kerja yang telah diasaskan oleh Walton (1973). Model ini merangkumi lapan dimensi utama, iaitu: (a) pulangan yang adil (fair compensation); (b) keselamatan dan kesihatan (safety and health); (c) pembangunan kendiri (self-development); (d) perkembangan dan keselamatan (growth and security); (e) sosial integrasi (social integration); (f) peraturan (Constitutionalism); (g) ruang kehidupan (life space); dan (h) keberkaitan sosial (social relevance).

Model Walton (1973) ini telah banyak diaplikasikan dalam pelbagai konteks kajian seperti dalam sektor swasta, awam, pembinaan dan perkhidmatan dan pendidikan (Baleghizadeh, Gordani \& Beheshti, 2012; Hamidi \& Mohamadi, 2012; Manju, 2014). Walau bagaimanapun, di Malaysia, kajian tentang kualiti kehidupan kerja masih terhad (Mohd Hanefah, Md Zain, Mat Zain \& Ismail, 2003) dan hal ini paling ketara terutamanya dalam bidang pendidikan. Hal ini mungkin berpunca daripada ketidakpastian akan kerangka teori yang sesuai diaplikasikan dalam konteks pendidikan dan agak ketinggalan berbanding dengan disiplin lain seperti dalam bidang tingkah laku manusia dalam organisasi dan pengurusan sumber manusia (Louis, 1998). Tambahan pula, pengkonsepsian kualiti kehidupan kerja guru dalam konteks Malaysia juga didapati amat kurang dibincangkan dan ini memberikan satu justifikasi untuk mengkonsepsi kualiti kehidupan kerja guru dalam konteks Malaysia berdasarkan empat teori utama, iaitu (a) teori sistem sosio-teknikal, (b) teori dua faktor Herzberg; (c) teori pengurusan organisasi yang merangkumi teori struktur dan teori perhubungan manusia, dan (d) teori psikologikal interaktif. Perbincangan berkaitan keempat-empat teori ini dijelaskan dalam bahagian kerangka teoretikal kajian. Kajian ini juga membina satu instrumen yang boleh dipercayai dengan kesahannya terjamin dalam mengukur kualiti kehidupan kerja guru dalam konteks pendidikan di Malaysia.

\subsection{KERANGKA TEORI}

Sebagai asas untuk mengkonsepsi dan membina instrumen kualiti kehidupan kerja guru, empat teori, iaitu (a) teori sistem sosio-teknikal, (b) teori dua faktor Herzberg; (c) teori pengurusan organisasi yang merangkumi teori struktur dan teori perhubungan manusia, dan (d) teori psikologikal interaktif telah dipilih sebagai asas yang bersesuaian dengan tujuan kajian ini untuk membina satu kerangka teoretikal kualiti kehidupan kerja guru yang berbeza daripada model yang dikemukakan oleh Walton $(1973,1975)$

\section{Teori Sistem Sosio-Teknikal}

Teori sistem sosio-teknikal merujuk kepada integrasi antara aspek sosial dan teknikal di dalam organisasi. Objektif utama pendekatan teori sistem sosio-teknikal ialah untuk mengoptimumkan gabungan antara matlamat organisasi dan keperluan-keperluan pekerja (Cherns \& Davis, 1975). Teori ini mengandaikan bahawa setiap organisasi terdiri daripada manusia (sistem sosial) yang menggunakan alat, teknik dan pengetahuan (sistem teknikal) untuk menghasilkan perkhidmatan yang bermutu untuk pelanggan yang berada di luar organisasi. Teras utama kualiti kehidupan kerja dari perspektif teori sosio-teknikal ialah menjadikan kerja lebih menarik dan mencabar dengan mereka bentuk semula struktur kerja dan ciri organisasi kerja. Berdasarkan prinsip-prinsip teori sistem sosio-teknikal ini, Trist (1983) menyatakan bahawa pengurus menganggap pekerja sebagai manusia biasa yang mempunyai minat dan impian, motivasi dan harapan, kekuatan dan kelemahan. Produktiviti organisasi dan sumber tenaga manusia di dalamnya akan seiring meningkat dengan memberi fokus dan menitikberatkan kepada kebergantungan hubungan antara manusia (pekerja), teknologi dan persekitaran (Brooks \& Anderson, 2005). Oleh itu, sebarang proses reka bentuk kerja oleh organisasi perlu mempertimbangkan impak antara sistem (sosial) dengan sistem (teknikal). Hal ini bertujuan untuk memastikan kedua-dua subsistem ini bekerja dengan harmoni dan dapat memenuhi keperluan-keperluan pekerja yang boleh meningkatkan kualiti kehidupan kerja anggotanya.

\section{Teori Dua Faktor Herzberg}

Menurut Herzberg, Mausner dan Snyderman (2010), terdapat dua faktor berasingan di tempat kerja yang mempengaruhi kepuasan kerja dan ketidakpuasan kerja. Hasil kajian yang dijalankan oleh Herzberg (1966) terhadap 203 akauntan dan jurutera di Pittsburg telah mencadangkan dua set faktor keperluan yang berbeza dalam mempengaruhi kepuasan dan ketidakpuasan kerja seseorang. Faktor pertama dikelaskan sebagai faktor pendorong (motivator) iaitu berkaitan dengan perasaan positif terhadap kerja dan perkara-perkara yang 
berhubung dengan kerja termasuklah pencapaian, pengiktirafan, pekerjaan yang bermakna, penghormatan, perkembangan dan pertumbuhan individu itu sendiri yang membawa kepada kepuasan kerja. Manakala faktor kedua dikenali sebagai faktor 'hygiene' yang berkaitan dengan persekitaran kerja itu sendiri daripada aspek fizikal dan psikologi seperti polisi syarikat dan pentadbiran, penyeliaan, hubungan interpersonal, suasana tempat kerja, dan keselamatan yang menyebabkan ketidakpuasan kerja (Herzberg, 1966).

Konsep teori dua faktor Herzberg ini bertepatan dengan definisi yang dinyatakan oleh Yousuf (1996) dan Fitzsimmons (2002) yang menekankan bahawa faktor-faktor yang hampir sama dalam menentukan kepuasan kerja iaitu seperti keselamatan pekerjaan, ganjaran dan faedah, suasana kerja, organisasi, hubungan interpersonal dan kepuasan kerja. Sehubungan dengan ini, pentadbir dalam sesebuah organisasi perlu memberi penekanan kepada faktor-faktor dalam memenuhi keperluan pekerjanya sekiranya ingin meningkatkan kepuasan kerja dan memberi tumpuan kepada persekitaran kerja untuk mengurangkan ketidakpuasan kerja. Cara ini akan meningkatkan kualiti kehidupan kerja pekerja di samping mengekalkan tenaga kerja yang berkualiti dan bermotivasi dalam organisasi.

\section{Teori Pengurusan Organisasi}

Blau dan Scott (1962) serta Thompson (1967) berpendapat bahawa kaedah yang paling baik untuk mengukuhkan organisasi dan pengurusan organisasi ialah dengan membina struktur organisasi yang disesuaikan dengan hasrat ahli organisasi serta suasana atau persekitaran pengurusannya. Mengikut perspektif teori ini, organisasi membahagikan tugas dan tanggungjawab kepada ahli-ahlinya melalui pernyataan dasar, peraturan dan hierarki pengurusan supaya pelbagai aktiviti dalam organisasi tersebut dapat diselaraskan. Organisasi akan menghadapi masalah sekiranya struktur yang ada dalam organisasi tidak selaras dengan kehendak ahli, aktiviti dan persekitaran kerja.

Sementara itu, tumpuan perspektif teori perhubungan manusia pula, ialah kepada ciri-ciri kemanusiaan dan perhubungan manusia dalam organisasi. Ahli-ahli teori perhubungan manusia dalam organisasi adalah seperti Argyris dan Schon (1978), Kotter (1982) dan Maslow (1954). Ahli-ahli teori ini berpendapat bahawa cara yang paling sesuai untuk mengurus organisasi ialah dengan menyesuaikan dan menghubungkan kehendak dan nilai seseorang itu dengan kehendak dan peraturan secara kumpulan yang diperlukan bagi mencapai matlamat organisasi. Mengikut teori ini lagi, organisasi akan menghadapi masalah sekiranya kehendak ahli-ahlinya diabaikan atau ditekan oleh pihak pengurusan. Justeru, tumpuan seharusnya diberikan untuk mewujudkan satu bentuk organisasi yang dapat memenuhi hak, keperluan dan kepuasan individu yang memberikan kesan langsung kepada peningkatan kualiti kehidupan kerja pekerja (Yousof, 1996).

\section{Teori Psikologikal Interaktif}

Teori psikologikal interaktif ini menjelaskan tentang pengalaman manusia dalam bentuk perhubungan atau interaksi antara seseorang individu dengan peluang-peluang yang terdapat dalam persekitaran mereka (French, Caplan, \& Van Harrison, 1982; French, Rogers, \& Cobb, 1974; Terborg, 1983). Teori ini menyatakan manusia memerlukan keperluan-keperluan mereka dipenuhi oleh persekitaran mereka dan memberikan pengalaman afektif yang positif. Menurut teori ini, semakin positif pengalaman afektif pekerja maka mereka akan bersikap dan bertingkahlaku lebih positif serta semakin bermotivasi untuk memberikan respon yang lebih baik kepada persekitaran tersebut.Teori ini mengkategorikan keperluan-keperluan manusia yang pelbagai itu kepada empat kumpulan, iaitu (a) keperluan asas kepada kelangsungan atau kemandirian hidup (survival need) yang merangkumi keselamatan dan ekonomi, (b) keperluan sosial yang menitikberatkan hubungan interpersonal, persahabatan, penerimaan dan penglibatan dalam kumpulan, (c) keperluan ego iaitu keinginan untuk mendapat sanjungan dan penghormatan dari orang lain, mempunyai autonomi dan rasa dihargai, dan (d) keperluan memperkembangkan potensi diri (self-actualization need). Teori ini mengandaikan bahawa jika keperluan-keperluan individu dalam persekitarannya itu dapat dipenuhi, maka ini akan meningkatkan kualiti kehidupan kerja individu atau kumpulan dalam organisasi itu yang membolehkan mereka memberi respon yang lebih positif kepada kemajuan organisasi. Oleh itu, fokus untuk mewujudkan persekitaran kerja yang kondusif adalah penting untuk memberikan pengalaman positif yang dapat memotivasikan pekerja dan meningkatkan kepuasan. Implikasi utama ialah kualiti kehidupan kerja pekerja bertambah baik serta menjamin peningkatan produktiviti dan kecemerlangan sesuatu organisasi (Davis, 1985; Feuer, 1989).

Berdasarkan perbincangan berkaitan dengan teori-teori ini, dapat disimpulkan bahawa individu akan berusaha memenuhi keperluan asas melalui pekerjaan yang dilakukannya. Setakat mana setiap pekerja itu dapat memenuhi keperluan ini akan menentukan tahap kualiti kehidupan kerjanya dan kepuasan terhadap kerja yang dilakukannya. Keempat-empat teori yang dibincangkan ini jelas menunjukkan terdapatnya keperluan pekerja dari aspek psikologi (teori psikologi interaktif), sosial (teori sistem teknikal dan teori psikologi interaktif), politik (teori pengurusan organisasi dan psikologi interaktif) dan ekonomi (teori psikologi interaktif dan teori dua faktor Herzberg) perlu dipenuhi untuk membolehkan matlamat organisasi tercapai serta dapat mewujudkan kualiti kehidupan kerja yang cemerlang dalam kalangan pekerja.

Berdasarkan teori-teori ini, sekolah yang dianggap sebagai sebuah organisasi yang mempunyai sumber manusia yang terdiri daripada kumpulan pentadbir, guru, staf sokongan dan murid serta berlaku hubungan sosial dan aspek teknikal untuk mencapai objektif organisasi. Teori sistem sosio-teknikal mengandaikan bahawa pekerja akan lebih bertanggungjawab jika kerja yang dilakukan dapat memenuhi keperluan psikologinya (Pasmore et al., 1982).

Dari perspektif teori pengurusan organisasi pula, organisasi sekolah perlu mengorganisasi struktur kerja dan peranan yang formal melalui pembahagian tugas dan tanggungjawab mengikut dasar, peraturan dan hierarki pengurusan yang telah ditetapkan. Sekolah juga perlu memenuhi pelbagai keperluan guru-guru seperti yang dinyatakan dalam teori psikologikal interaktif bagi mewujudkan kualiti kehidupan kerja guru. Tumpuan harus diberikan kepada strategi untuk memenuhi keperluan dan kehendak warga sekolah terutamanya guru-guru seiring dengan keperluan pencapaian matlamat organisasi sekolah. Rajah 1 menunjukkan kerangka teori yang mendasari pengkonsepsian baru kualiti kehidupan kerja guru dalam kajian ini. 


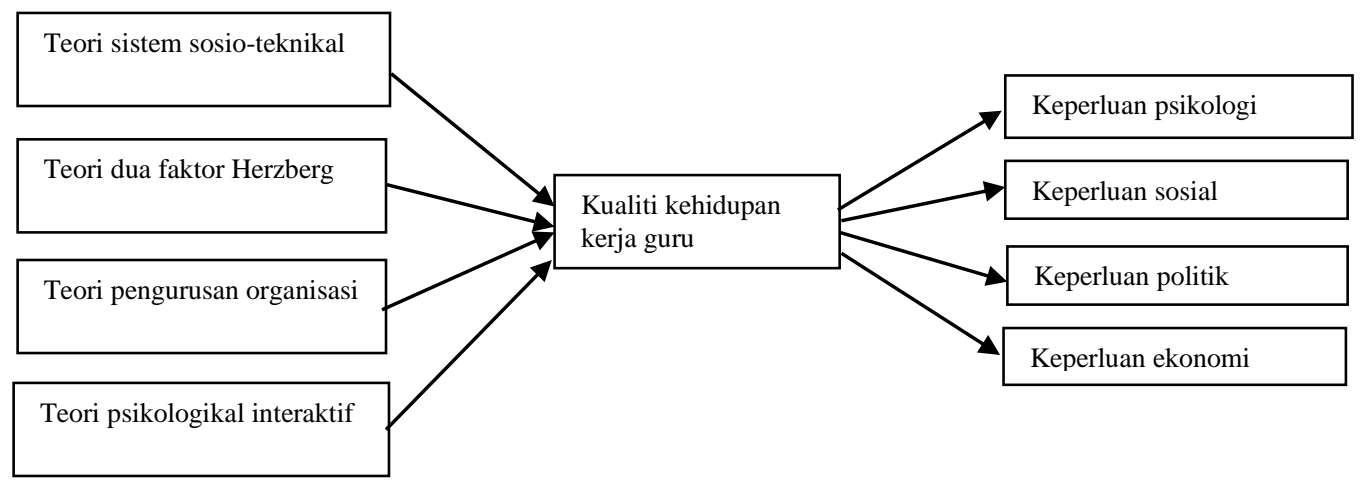

Rajah 1 Kerangka teori kualiti kehidupan kerja guru

\subsection{PENGKONSEPSIAN KUALITI KEHIDUPAN KERJA GURU}

Berdasarkan perspektif teori yang telah dibincang, kualiti kehidupan kerja guru dapat dinyatakan setakat mana keupayaan organisasi sekolah dan persekitaran kerja sekolah yang dapat menyokong dan memenuhi keperluan-keperluan guru dari aspek psikologi, sosial, politik dan ekonomi dengan menyediakan peluang-peluang untuk maju dan memperkembangkan potensi diri, kenaikan pangkat, penghargaan dan keselamatan pekerjaan.

\section{Keperluan Psikologi}

Keperluan psikologi bermaksud sejauh mana keadaan dalam organisasi sekolah dapat memenuhi keperluan psikologi guru, iaitu penghakikian kendiri, penghormatan kendiri dan kebanggaan kendiri. Dimensi aspek psikologi ini boleh dilihat daripada komponen yang dikemukakan oleh Rossmiller (1992) dan Louis (1998), iaitu penghormatan daripada pihak pentadbiran sekolah, waris dan masyarakat (Firestone \& Rosenblum, 1988) dapat memberikan kepuasan kendiri yang tinggi kepada guru (Rosenholtz, 1989). Prinsip asas kepada kualiti kehidupan kerja ialah individu ingin memenuhi keperluan psikologi mereka melalui pekerjaan yang membawa kepada kepuasan kerja seperti penghormatan, pengiktirafan dan penghargaan oleh organisasi di mana pekerja itu bekerja. Penghormatan yang diberikan kepada pekerja akan memberikan kesan positif serta dapat meningkatkan tahap motivasi dan produktiviti pekerja (Fitzsimmons, 2002; Yousuf, 1996). Teori dua faktor Herzberg turut menyumbang kepada pembentukan keperluan psikologi apabila aspek motivator yang terdiri daripada faktor pencapaian, pengiktirafan, penghormatan, dan kepuasan hati membawa kepada kepuasan kerja yang memenuhi keperluan psikologi pekerja. Oleh itu, sekolah perlu berusaha untuk memenuhi keperluan psikologi guru-gurunya agar guru lebih gembira, seronok dan lebih produktif. Contoh item mengukur keperluan psikologi dalam kalangan guru termasuklah 'saya merasa terasing daripada rakan sekerja' dan 'saya dihargai kerana kebolehan saya'.

\section{Keperluan Sosial}

Keperluan sosial bermaksud sejauh mana keadaan dalaman organisasi sekolah dapat memenuhi keperluan sosial guru, iaitu dari aspek hubungan dengan rakan sekerja, kolaborasi dan keselesaan bekerja. Dimensi yang menyumbang kepada keperluan sosial dikemukakan oleh Louis (1998), dan Rossmiller (1992), iaitu bekerja secara kolaboratif antara rakan sejawat yang pelbagai jawatan tanpa ada perbezaan status jawatan (Little, 1984; Rosenholtz, 1989). Sturman (2003) pula menyatakan aspek perhubungan dengan rakan sejawat. Manakala dalam bidang bukan pendidikan, dimensi keperluan sosial dapat dilihat melalui pendapat yang dikemukakan oleh Hsu dan Kernohan (2005) and Taylor (1978) iaitu integrasi sosial dalam organisasi pekerjaan, keselamatan tempat kerja dan persekitaran kerja yang sihat. Teori sistem sosio-teknikal juga boleh diadaptasi untuk membentuk dimensi keperluan sosial di mana terdapatnya gabungan antara matlamat organisasi dan keperluan pekerja (Cherns \& Davis, 1975). Perhubungan dan kerjasama yang baik antara guru dengan guru dan guru dengan pentadbir sekolah boleh membantu sekolah mencapai matlamat untuk melahirkan modal insan berkualiti. Contoh item mengukur keperluan sosial dalam kalangan guru termasuklah 'saya bekerja dengan rakan-rakan yang melaksanakan tugas dengan baik' dan 'saya percaya dengan rakan sekerja saya'.

\section{Keperluan Politik}

Keperluan politik bermaksud sejauh mana keadaan dalaman organisasi sekolah dapat memenuhi keperluan politik guru, iaitu demokrasi dan autonomi, kepercayaan dan kejujuran rakan sekerja dan keadilan serta konflik dalam sekolah. Peluang guru terlibat dalam membuat keputusan adalah penting dalam sesebuah organisasi seperti sekolah (Cohen, Kottkamp, McCloskey, \& Provenzo, 1987; Firestone \& Rosenblum, 1988) dan merupakan salah satu aspek dalam dimensi keperluan politik (Louis, 1998 ; Rossmiller, 1992 ; Sturman, 2003). Tujuan utama melibatkan pekerja dalam proses membuat keputusan adalah kerana proses ini mempunyai kaitan yang penting dengan faktor moral, produktiviti dan kepuasan pekerja (Champion-Hughes, 2001). Kepercayaan yang diberikan kepada pekerja untuk sama-sama terlibat dalam proses membuat keputusan akan meningkatkan moral, produktiviti dan kepuasan pekerja. Pembentukan dimensi keperluan politik turut disumbang oleh pendapat yang dikemukakan oleh Feuer (1989), Hsu dan Kernohan (2005) dan Taylor (1978). Kajian lepas ini 
menekankan aspek pemberian kuasa autonomi kepada pekerja serta meningkatkan penglibatan pekerja dalam menentukan kehidupan kerja mereka. Oleh itu, dimensi keperluan politik merupakan faktor penting dalam menghasilkan kualiti kehidupan kerja guru yang baik dan perlu diukur dalam konteks sekolah-sekolah di Malaysia. Contoh item mengukur keperluan politik dalam kalangan guru termasuklah 'saya tertekan dengan konflik yang wujud di sekolah saya' dan 'saya berpuas hati dengan tahap etika kerja yang diamalkan'.

\section{Keperluan Ekonomi}

Keperluan ekonomi dikonsepsikan sebagai keadaan dalaman organisasi sekolah yang dapat memenuhi keperluan ekonomi guru seperti gaji, ganjaran dan pampasan. Pembentukan dimensi keperluan ekonomi mengambil kira pendapat yang dikemukakan oleh Hsu dan Kernohan (2005), Taylor (1978), Rohayati (1999), Sturman (2003), dan Yousuf (1996) yang memfokuskan kepada gaji dan ganjaran tambahan yang cukup dan adil untuk memastikan guru mempunyai kualiti kehidupan kerja yang baik. Sekiranya keperluan ekonomi tidak dipenuhi sebaiknya oleh organisasi, impaknya adalah ke atas kualiti kerja, kualiti kehidupan kerja pekerja, kehidupan keluarga, kehidupan sosial dan kehidupan secara keseluruhannya (Sirgy, Efraty, Siegel, \& Lee, 2001). Contoh item mengukur keperluan ekonomi termasuklah 'pendapatan bulanan mencukupi untuk saya menyara perbelanjaan keluarga saya' dan 'pendapatan bulanan membolehkan saya memiliki aset yang diingini'.

Berdasarkan perbincangan di atas, maka dapat dirumuskan bahawa kualiti kehidupan kerja guru dapat dikonsepsikan sebagai keupayaan organisasi sekolah dan persekitaran kerja di sekolah yang dapat menyokong dan memenuhi keperluan-keperluan psikologi, sosial, politik dan ekonomi guru dengan menyediakan peluang-peluang untuk memperkembangkan potensi diri, kenaikan pangkat, penghargaan dan keselamatan pekerjaan. Pengoperasian definisi bagi setiap dimensi keperluan guru disenaraikan dalam Jadual 1.

Jadual 1 Pengoperasian definsi bagi dimensi konstruk kualiti kehidupan kerja guru

\begin{tabular}{lcl}
\hline Dimensi & & \multicolumn{1}{c}{ Pengoperasian Definisi } \\
\hline Keperluan Psikologi & $\bullet$ & $\begin{array}{l}\text { Setakat mana keadaan dalaman organisasi sekolah dapat memenuhi keperluan psikologi guru, } \\
\text { seperti kehakikian kendiri, penghormatan kendiri dan kebanggaan kendiri. }\end{array}$ \\
\hline Keperluan Sosial & $\bullet$ & $\begin{array}{l}\text { Setakat mana keadaan dalaman organisasi sekolah dapat memenuhi keperluan sosial guru dari } \\
\text { aspek hubungan sosial guru dengan rakan sekerja dan tanggungjawab sosial seseorang guru. }\end{array}$ \\
\hline Keperluan Politik & $\bullet$ & $\begin{array}{l}\text { Setakat mana keadaan dalaman organisasi sekolah dapat memenuhi keperluan politik guru, iaitu } \\
\text { dari aspek demokrasi dan autonomi, kepercayaan dan kejujuran rakan sekerja dan keadilan. }\end{array}$ \\
\hline Keperluan Ekonomi & $\bullet$ & $\begin{array}{l}\text { Setakat mana keadaan dalaman organisasi sekolah dapat memenuhi keperluan ekonomi guru dari } \\
\text { segi penggajian, ganjaran dan pampasan. }\end{array}$ \\
\hline
\end{tabular}

\subsection{METODOLOGI}

Kajian ini menggunakan kaedah tinjauan untuk mendapatkan data daripada sampel dalam populasi kajian yang dipilih. Kaedah tinjaun dipilih disebabkan kajian ini melibatkan bilangan sampel yang ramai dan fakta-fakta dan maklumat yang terkumpul boleh diuji dengan menggunakan pelbagai kaedah statistik bagi menjelaskan fenomena yang dikaji. Maklumat daripada sampel diperolehi dengan menggunakan instrumen dalam bentuk soal selidik.

\section{Persampelan Kajian}

Terdapat dua peringkat persekolahan di Malaysia, iaitu sekolah rendah dan sekolah menengah, kajian ini memilih untuk mengkaji kualiti kehidupan kerja guru di tiga jenis sekolah rendah, iaitu, Sekolah Kebangsaan (SK), Sekolah Jenis Kebangsaan Cina (SJKC) dan Sekolah Jenis Kebangsaan Tamil (SJKT) yang menggunakan kurikulum yang sama tetapi bahasa pengantar yang berbeza yang dicirikan oleh tiga kumpulan etnik utama Malaysia, iaitu Melayu, Cina dan India. Rasional memberi tumpuan kajian adalah kerana ketiga-tiga kumpulan etnik ini mempunyai budaya yang unik, tradisi, kepercayaan dan nilai-nilai yang boleh mempengaruhi persepsi mereka dalam memberikan respons terhadap item-item di dalam instrumen (Gerstner \& Day, 1994; Spreitzer, Perttula, \& Xin, 2005). Justeru, wujud potensi untuk meneroka pengaruh orientasi budaya seseorang terhadap persepsi guru yang berlainan etnik tentang kualiti kehidupan kerja. Sejumlah 1,080 guru telah dipilih secara rawak daripada 90 buah sekolah yang terdiri daripada Sekolah Rendah Kebangasaan (30), Sekolah Jenis Kebangsaan Cina (30) dan Sekolah Jenis Kebangsaan Tamil (30) masing-masing di Pulau Pinang dan Kedah. Seramai 12 orang guru dipilih secara rawak dari setiap sekolah yang dipilih sebagai sampel kajian. Jadual 2 menunjukkan 81 peratus daripada sampel kajian utama ialah guru-guru perempuan manakala baki 19 peratus ialah guru-guru lelaki. Guru-guru ini dalam lingkungan umur antara 25 hingga 56 tahun. Bilangan guru dengan kelulusan akademik guru dalam kategori Sijil Pelajaran Malaysia (SPM), Sijil Tinggi Pelajaran Malaysia (STPM), Diploma dan Sarjana Muda adalah tidak jauh berbeza kecuali dalam kategori Sarjana. Lebih daripada 50 peratus daripada jumlah sampel kajian ialah guru biasa. Manakala baki 50 peratus adalah terdiri daripda guru-guru yang memegang jawatan sebagai Ketua Jabatan atau Ketua Panitia, Guru Penolong Kanan, guru darjah dan guru kaunseling atau guru media atau guru perpustakaan. 
Jadual 2 Maklumat demografi guru keseluruhan

\begin{tabular}{llll}
\hline Kategori & Deskripsi & Bilangan $(N=1080)$ & Peratus $(\%)$ \\
\hline Jantina & Lelaki & 204 & 18.9 \\
& Perempuan & 876 & 81.1 \\
\hline Tahap pendidikan & SPM/ MCE & 217 & 20.1 \\
& STPM/ HSC & 234 & 21.7 \\
& Diploma & 332 & 30.7 \\
& Ijazah & 270 & 25.0 \\
& Sarjana & 27 & 2.5 \\
\hline Jawatan guru & Guru biasa & 577 & 54.4 \\
& Guru darjah & 108 & 10.0 \\
& Kaunseling/Media/Perpustakaan & 66 & 6.1 \\
& Ketua Jabatan/ Ketua Panitia & 215 & 19.9 \\
& Guru Penolong Kanan & 114 & 10.6 \\
\hline
\end{tabular}

\section{Instrumen dan Prosedur Data Analysis}

Sejumlah 32 item dengan lapan item bagi dimensi telah dibina berdasarkan definisi operasi yang diberikan kepada setiap dimensi konstruk kualiti kehidupan kerja guru seperti yang dinyatakan dalam Jadual 1. Setiap item dalam soal selidik ini diukur dengan enam pilihan jawapan yang menggunakan 6-poin skala Likert. Pilihan respon adalah terdiri daripada (0) Sangat Tidak Setuju, (1) Tidak Setuju, (2) Sedikit Setuju, (3) Setuju, (4) Sangat Setuju dan (5) Sangat-sangat Setuju. Sebelum instrumen ini ditadbirkan kepada responden, penilaian terhadap kesahan kandungan telah dijalankan. Penilaian terhadap kesahan kandungan telah dilakukan oleh lima orang pensyarah dan guru. Maklumat latar belakang penilai yang terlibat dalam kesahan kandungan ditunjukkan dalam Jadual 3. Penilai 1 dan 2 dipilih bertujuan untuk melihat kesesuaian item dari sosial psikologi perspektif. Penilai ketiga dipilih untuk melihat kesesuaian pengukuran item bagi konstruk kualiti hidup kerja guru. Selain itu, seorang guru cemerlang dalam subjek Bahasa Melayu dipilih untuk mengenalpasti kualiti item dari segi kesesuaian bahasa. Manakala seorang guru cemerlang dalam subjek matematik dipilih untuk melihat kesesuaian item secara keseluruhannya. Kelima-lima penilai telah meneliti setiap item supaya kesahan kandungan terjamin mengikut kerangka teori yang mendasari kajian ini. Beberapa item didapati perlu diperbaiki. Contohnya, Item KPO5 'tahap saling mempercayai antara semasa rakan sekerja adalah tinggi' telah dimodifikasikan sebagai 'saya berpuas hati dengan tahap saling mempercayai sesama rakan sekerja'. Selain itu, item KPS6 'saya sentiasa diketepikan dalam sekolah ini' dimodifikasikan sebagai 'saya merasa terasing daripada rakan sekerja'.

Jadual 3 Maklumat penilai kesahan kandungan instrument

\begin{tabular}{lll}
\hline Penilai & Kepakaran/subjek mengajar & Pengalaman \\
\hline Pensyarah 1 & Psikologi pendidikan & 10 tahun \\
Pensyarah 2 & Sosiologi pendidikan & 6 tahun \\
Pensyarah 3 & Pengukuran dan penilaian & 5 tahun \\
Guru 1 & Matematik & 7 tahun \\
Guru 2 & Bahasa Melayu & 6 tahun \\
\hline
\end{tabular}

Tidak ada item yang digugurkan dan item-item yang bermasalah dari segi kesesuaian pernyataan dan interpretasi dibaiki mengikut perbincangan antara pengkaji dan penilai kandungan keesahan. Data yang dikumpulkan dalam kajian ini dianalisis dengan analisis faktor eksploratori (Exploratory Factor Analysis) dan analisis faktor konfirmatori (Confirmatory Factor Analysis) dengan program computer IBM SPSS 20 dan AMOS 20 masing-masing. Tujuan penggunaan analisis faktor eksploratori dengan pendekatan principal component analysis (PCA) adalah untuk menentukan sama ada item-item yang dibina itu dikumpulkan ke dalam dimensi atau faktor tertentu yang membentuk konstruk kualiti kehidupan kerja guru seperti yang dibincangkan dalam Seksyen 3.0. Manakala analisis faktor konfirmatori bertujuan mengesahkan item-item yang dikenalpasti dalam analisis faktor eksploratori berada dalam dimensi berkenaan bagi konstruk kualiti kehidupan kerja guru. Sejumlah 1,080 sampel kajian telah dibahagikan kepada dua set sampel. Sampel pertama terdiri daripada 500 orang guru sekolah rendah untuk tujuan analisis faktor exploratori manakala baki 580 orang guru sekolah rendah untuk tujuan analisis faktor konfirmatori.

\subsection{DAPATAN KAJIAN}

Jadual 4 menunjukkan keputusan analisis faktor eksploratori. Hanya item yang mempunyai muatan faktor melebihi .50 dikekalkan dan dikenalpasti menyumbang kepada pembinaan dimensi tersebut (Hair, Black, Babin, \& Anderson, 2010). Sebanyak 11 item daripada 32 item asal telah dikeluarkan kerana tidak memenuhi nilai muatan faktor .50 yang ditetapkan sebagai nilai rujukan dalam kajian ini (Nunally \& Bernstein, 1994). Baki 21 items dikumpulkan dalam empat faktor yang mempunyai nilai eigen yang nilainya melebihi 1.0. Keempatempat faktor ini dilabelkan sebagai keperluan politik (7 item), keperluan sosial (7 item), keperluan ekonomi (4 item) dan keperluan psikologi (3 item) berdasarkan kepada makna setiap item di dalam setiap faktor yang diekstrak daripada analisis faktor eksploratori. Sementara itu, purata varians diekstrak bagi empat faktor tersebut berada dalam lingkungan tujuh dan 45 peratus. 
Jadual 4 Keputusan analisis faktor eksploratori

\begin{tabular}{|c|c|c|c|c|}
\hline \multirow[b]{2}{*}{ Item } & \multicolumn{4}{|c|}{ Muatan Faktor } \\
\hline & KPO & KSO & KPE & KPS \\
\hline KPO2 & 0.92 & & & \\
\hline KPO3 & 0.91 & & & \\
\hline KPO4 & 0.95 & & & \\
\hline KPO5 & 0.90 & & & \\
\hline KPO6 & 0.92 & & & \\
\hline KPO7 & 0.83 & & & \\
\hline KPO8 & 0.82 & & & \\
\hline KSO1 & & 0.84 & & \\
\hline $\mathrm{KSO} 2$ & & 0.90 & & \\
\hline KSO3 & & 0.91 & & \\
\hline KSO4 & & 0.82 & & \\
\hline KSO6 & & 0.69 & & \\
\hline KSO7 & & 0.85 & & \\
\hline KSO8 & & 0.89 & & \\
\hline KPE3 & & & 0.51 & \\
\hline KPE5 & & & 0.92 & \\
\hline KPE6 & & & 0.89 & \\
\hline KPE7 & & & 0.88 & \\
\hline KPS5 & & & & 0.89 \\
\hline KPS6 & & & & 0.86 \\
\hline KPS7 & & & & 0.91 \\
\hline Nilai Eigen & 9.35 & 2.79 & 2.13 & 1.63 \\
\hline Purata Varians diekstrak (\%) & $44.54 \%$ & $13.31 \%$ & $10.12 \%$ & $7.75 \%$ \\
\hline
\end{tabular}

Jadual 5 menunjukkan muatan faktor untuk item-item melebihi nilai rujukan 0.70 dalam analisis faktor Konfirmatori yang dicadangkan oleh Chin (1998). Item KPE3 digugurkan disebabkan nilai muatan faktornya, 0.54 yang jauh lebih rendah daripada 0.70. Nilai purata varians yang diekstrak untuk setiap dimensi didapati melebihi nilai 0.50. Sementara itu, kebolehpercayaan komposit bagi setiap dimensi kualiti kerja kehidupan guru melebihi nilai 0.70 menunjukkan konsistensi antara item dalam mengukur setiap dimensi kualiti kerja kehidupan guru. Kebolehpercayaan Cronbach's alpha juga melebihi nilai rujukan 0.70 seperti yang dicadangkan oleh Nunnally dan Bernstein (1994). Bukti-bukti ini menunjukkan kewujudan kesahan konvergen bagi konstruk kualiti kerja kehidupan guru. Sementara itu kesahan diskriminan bagi menunjukkan sejauh mana item-item dapat membezakan antara dimensi dalam konstruk kualiti kerja kehidupan guru ditentukan menggunakan kriteria yang dicadangkan oleh Fornell dan Lacker (1981). Menurut Fornell dan Lacker (1981), item-item sepatutnya tergolong dan mengukur setiap dimensi dan tidak mengukur dimensi lain dalam konstruk yang diukur. Oleh itu, punca kuasa dua varians yang dikongsikan antara item dalam setiap dimensi perlulah lebih besar nilainya daripada kolerasi antara dimensi yang membina konstruk kualiti kerja kehidupan guru.

Jadual 5 Keputusan analisis faktor konfirmatori

\begin{tabular}{|c|c|c|c|c|}
\hline \multirow[b]{2}{*}{ Item } & \multicolumn{4}{|c|}{ Muatan Faktor } \\
\hline & KPO & KSO & KPE & KPS \\
\hline $\mathrm{KPO} 2$ & 0.90 & & & \\
\hline KPO3 & 0.90 & & & \\
\hline KPO4 & 0.92 & & & \\
\hline KPO5 & 0.91 & & & \\
\hline KPO6 & 0.92 & & & \\
\hline KPO7 & 0.79 & & & \\
\hline KPO8 & 0.79 & & & \\
\hline KSO1 & & 0.81 & & \\
\hline $\mathrm{KSO} 2$ & & 0.86 & & \\
\hline KSO3 & & 0.86 & & \\
\hline $\mathrm{KSO} 4$ & & 0.80 & & \\
\hline KSO6 & & 0.75 & & \\
\hline KSO7 & & 0.82 & & \\
\hline KSO8 & & 0.86 & & \\
\hline KPE5 & & & 0.86 & \\
\hline KPE6 & & & 0.85 & \\
\hline KPE7 & & & 0.80 & \\
\hline KPS5 & & & & 0.88 \\
\hline KPS6 & & & & 0.80 \\
\hline KPS7 & & & & 0.82 \\
\hline Purata Varians diekstrak & 0.77 & 0.68 & 0.70 & 0.69 \\
\hline Kebolehpercayaan Komposit & 0.96 & 0.94 & 0.87 & 0.87 \\
\hline Kebolehpercayaan (Cronbach Alfa) & 0.96 & 0.93 & 0.86 & 0.87 \\
\hline
\end{tabular}

Petunjuk: KPO= Keperluan politik, KSO=Keperluan sosial, KPE=Keperluan ekonomi, $\quad$ KPS=Keperluan psikologi 
Jadual 6 menunjukkan punca kuasadua varians yang diekstrak (nilai pada pepenjuru yang dihitamkan) adalah lebih besar daripada korelasi antara dimensi dalam konstruk kualiti kerja kehidupan guru. Dapatan ini menunjukkan bahawa kesahan diskriminan bagi konstruk kualiti kerja kehidupan guru adalah dipenuhi. Keputusan ini menunjukkan kewujudan kesahan konstruk bagi kualiti kerja kehidupan guru.

Jadual 6 Kesahan diskrimninan konstruk

\begin{tabular}{lllll}
\hline & KPO & KSO & KPE & KPS \\
\hline KPO & $\mathbf{0 . 8 8}$ & & & \\
KSO & 0.54 & $\mathbf{0 . 8 2}$ & & \\
KPE & 0.38 & 0.28 & $\mathbf{0 . 7 7}$ & \\
KPS & 0.36 & 0.50 & 0.24 & $\mathbf{0 . 8 3}$ \\
\hline
\end{tabular}

Selain itu, model pengukuran untuk konstruk kualiti kerja kehidupan guru ini juga menunjukkan keserasian dengan data yang dikumpulkan. Nilai 'goodness-of-fit' bagi model ini menunjukkan nilai chi-square adalah signifikan $\left(\chi^{2}(183)=1289.862, p<.001\right)$. Oleh kerana nilai chi-square dipengaruhi oleh saiz sampel, nilai 'goodness-of-fit' yang diberikan oleh perisian AMOS 20.0 digunakan untuk menentukan keserasian model dengan data. Berdasarkan keputusan analisis, cmin/darjah kebebasan ialah 7.05, nilai ini didapati lebih tinggi daripada nilai rujukan antara 3.0 and 5.0 (Schumaker \& Lomax, 2004). Walaubagaimanapun, nilai CFI (comparative fit index) ialah .941 melebihi nilai rujukan .90 (Hooper, Coughlan, \& Mullrn, 2008), TLI (Tucker-Lewis index) ialah .933 melebihi nilai rujukan .90 (Hu \& Bentler, 1999) dan nilai RMSEA (root mean-square of error approximation) pula ialah .075 dengan $90 \%$ julat keyakinan antara 0.071 dan 0.079 yang berada dalam julat rujukan yang dicadangkan oleh MacCallum, Browne dan Sugawara (1996). Dapatan ini menunjukkan model adalah serasi dengan data. Sejumlah 20 items yang sah dan boleh dipercayai dalam mengukur kualiti kehidupan kerja guru disenaraikan dalam Jadual 7.

Jadual 7 Item deskripsi

\begin{tabular}{lll}
\hline Dimensi & Item & Deskripsi \\
\hline Keperluan & KPO2 & Saya tertekan dengan konflik yang wujud di sekolah saya. \\
Politik & KPO3 & Koordinasi kerja antara kumpulan kerja di sekolah ini amat baik. \\
& KPO4 & Persaingan antara kumpulan guru di sekolah menimbulkan masalah dalam menyelesaikan kerja. \\
& KPO5 & Saya berpuas hati dengan tahap saling mempercayai sesama rakan sekerja. \\
& KPO6 & Saya berpuas hati dengan tahap kejujuran rakan sekerja. \\
& KPO7 & Saya diberi peluang untuk membuat keputusam berdasarkan pertimbangan saya sendiri. \\
& KPO8 & Saya berpuas hati dengan tahap etika kerja yang diamalkan. \\
Keperluan & KSO1 & Saya bekerja dengan rakan-rakan yang melaksanakan tugas dengan baik. \\
Sosial & KSO2 & Saya percaya dengan rakan sekerja saya. \\
& KSO3 & Saya bekerjasama dengan baik dengan rakan sekerja. \\
& KSO4 & Kami terlibat bersama-sama dalam membuat keputusan. \\
& KSO6 & Semua pendapat ahli kumpulan diberikan perhatian. \\
& KS07 & Kami saling menggalakkan antara satu sama lain untuk memberikan hasil yang terbaik. \\
& KS08 & Secara keseluruhanna, saya berpuas hati dengan rakan sekerja saya. \\
Keperluan & KPE5 & Pendapatan bulanan mencukupi untuk saya menyara perbelanjaan keluarga saya. \\
Ekonomi & KPE6 & Pendapatan bulanan membolehkan saya memiliki aset yang diingini. \\
& KPE7 & Pendapatan bulanan membolehkan saya melakukan amalan kebajian (menderma, bersedekah). \\
Keperluan & KPS5 & Saya melakukan banyak kerja untuk sekolah tetapi tidak dihargai. \\
Psikologi & KPS6 & Saya merasa terasing daripada rakan sekerja. \\
& KPS7 & Saya dihargai kerana kebolehan saya. \\
\hline
\end{tabular}

\subsection{PERBINCANGAN DAN KESIMPULAN}

Kajian ini bertujuan mengkonsepsikan konstruk kualiti kerja kehidupan guru dengan empat dimensi utama, iaitu (1) keperluan psikologi, (2) keperluan sosial, (3) keperluan politik, dan (4) keperluan ekonomi. Terdapat empat teori utama, iaitu (1) teori sistem sosio-teknikal, (2) teori dua faktor Herzberg, (3) teori pengurusan organisasi yang merangkumi teori struktur dan teori perhubungan manusia, dan teori psikologikal interaktif yang mendasari pengkonsepsian konstruk kualiti kerja kehidupan guru.

Kualiti kehidupan kerja juga merupakan satu tret yang bersifat abstrak dan perlu diukur dengan menggunakan satu instrumen yang sah dan boleh dipercayai iaitu instrumen yang mempunyai item-item yang berkualiti. Justeru itu, satu instrumen dalam bentuk soal selidik telah dibina bagi mengukur konstruk kualiti kehidupan kerja guru dan dimensi-dimensinya merentas kumpulan etnik guru-guru sekolah rendah di Malaysia, iaitu SK, SJKC dan SJKT. Item-item telah dibina dan ditentukur dengan menggunakan analisis faktor eksploratori dan konfirmatori dengan menggunakan dua set sampel yang berlainan. Bukti empirikal yang diperolehi daripada kedua-dua analisis ini menunjukkan bahawa sebanyak 20 item telah menunjukkan kesahan dan kebolehpercayaan yang boleh digunakan dalam mengukur kualiti kehidupan kerja guru di sekolah rendah di Malaysia.

Dapatan daripada analisis faktor eksploratori dan analisi faktor konfirmatori yang menghasilkan empat dimensi yang mendasari kualiti kehidupan kerja guru jelas menunjukkan keserasian dengan kerangka kajian. Nilai purata varian diekstrak sebanyak $44.54 \%$ and 
77\% (lihat Jadual 4 dan Jadual 5) jelas menunjukkan keperluan politik menyumbangkan variansi yang tertinggi dalam konstruk kualiti kehidupan guru berbanding dengan dimensi lain. Ini membuktikan dapatan kajian menyokong teori pengurusan organisasi dan psikologi interaktif yang mendasari konsep kualiti kehidupan guru di sekolah. Kajian turut menunjukkan guru-guru menitikberatkan aspek demokrasi, autonomi dalam membuat keputusan, kejujuran rakan sekerja dan keadilan dalam menentukan tahap kualiti kehidupan mereka di sekolah. Keputusan ini adalah sejajar dengan kajian awal seperti Feurer (1989) serta Hsu dan Kernohan (2005).

Terdapat dua implikasi daripada kajian ini terhadap bidang pengetahuan dan polisi pendidikan. Kajian ini telah dapat membina satu kerangka teori bagi mengukur kualiti kehidupan kerja guru di sekolah-sekolah di Malaysia berdasarkan kepada empat teori utama. Instrumen yang dibina telah melalui proses saringan yang ketat untuk menentukan instrumen ini sesuai dan sah digunakan dalam konteks Malaysia yang berbilang budaya. Selain itu, model pengukuran yang dibangunkan ini seterusnya boleh diuji lagi untuk menilai kesaksamaan pengukuran (measurement equivalence) merentas tiga jenis sekolah rendah yang dipilih sebagai sampel kajian ini melalui teknik analisis faktor konfirmatori pelbagai kumpulan (multigroup confirmatory factor analysis). Perkara ini penting diberi perhatian untuk memastikan bahawa model pengukuran yang telah diuji dan skor setiap konstruk itu boleh membuat perbandingan.

Instrumen kualiti kehidupan kerja guru ini boleh digunakan oleh pentadbir sekolah dan pembuat dasar di peringkat daerah, negeri dan kebangsaan untuk mengukur kualiti kehidupan kerja guru di sekolah-sekolah di Malaysia. Sekiranya konsep ini mendapat perhatian di peringkat kebangsaan, kualiti kehidupan kerja guru yang baik akan tercapai dan seterusnya memberikan kesan yang positif terhadap institusi pendidikan dan meningkatkan kualiti modal insan. Perkara ini adalah penting kerana kajian-kajian terdahulu yang dijalankan telah menunjukkan bahawa kualiti kehidupan kerja mempunyai impak yang signifikan terhadap respon tingkah laku pekerja seperti kepuasan kerja, penglibatan kerja, usaha kerja, prestasi kerja, hasrat untuk berhenti, perubahan organisasi dan pengasingan diri.

Pengukuran konstruk kualiti kehidupan kerja guru dalam kajian ini dijalankan menggunakan kaedah kuantitatif. Dapatan kajian dipersembahkan dalam bentuk statistik dari bukti-bukti empirikal psikometrik. Kajian berbentuk kualitatif dijangka dapat menjelaskan keempat-empat dimensi yang mendasari pengkonsepsian konstruk kualiti kehidupan kerja guru dengan lebih mendalam lagi. Kajian masa depan boleh dijalankan untuk membuat perbandingan di antara konstruk kualiti kehidupan kerja guru terhadap variabel demografi yang lain seperti status perkahwinan, tahap pendidikan guru dan pengalaman mengajar. Cadangan kajian ini membolehkan pengkaji mengenal pasti adakah wujud perbezaan yang signifikan antara variabel-variabel tersebut terhadap konstruk yang dikaji. Selain itu, adalah dicadangkan bahawa kajian pada masa depan dapat melibatkan saiz sampel yang lebih besar yang dipilih dari negeri-negeri lain supaya dapatan kajian dapat digeneralisasikan secara menyeluruh dalam konteks Malaysia.

\section{Rujukan}

Argyris, C., \& Schon, D. (1978). Organizational Learning: A Theory of Action Perspective. Addison: Wesley.

Arthy, M., \& Nadhini, M. (2016). A Study on Quality of Work Life among the Engineering College Faculty Members in Coimbatore District.. International Journal of Management Research and Review, 6(8), 1051-1057.

Baleghizadeh, S., Gordani, Y. \& Beheshti, S. (2012). Motivation and Quality of Work Life among Secondary School EFL Teachers. Australian Journal of Teacher Education, 37(7), 30-42.

Blau. P., \& Scott, W. R. (1962). Formal Organization A Comparative Approach. San Francisco: Chandler.

Brooks, N., \& Anderson, G. (2005). Health Performance Measurement in Canada: Who's Doing What? Hospital Quarterly, 2(2), 22-26.

Champion-Hughes, R. (2001). Totally Integrated Employee Benefits. Public Personnel Management, 30(3), 287-302.

Cherns, A., \& Davis, L. (1975). The Quality of Work Life. New York: Free Press.

Chin, W.W. (1998). The Partial Least Squares Approach to Structural Equation Modeling. In G. A. Marcoulides (ed.), Modern Methods for Business Research (pp. 295-358). London: Lawrence Erlbaum Associates, Mahwah.

Cohen, M.M., Kottkamp, R.B., McCloskey, G.N., \& Provenzo, E.F. (1987). Teachers Perspective on Problems of their Profession: Implications for Policy Makers and Practitioners. Washington, DC: U.S. Department of Education, Office of Educational Research and Improvement.

Cummings, T. G., \& Malloy, E. S. (1977). Improving Productivity and the Quality of Work Life. New York: Praeger.

Darling-Hammond, L. (2000). Teacher Quality and Student Achievement: A Review of State Policy Evidence. Education Policy Analysis Archives, 8 (1). Retrieved from http://epaa.asu.edu/epaa/v8n1

Davis, K. (1985). Human Behavior at Work: Organization Behaviour. New York: McGraw-Hill.

Edwards, J. A., Van Laar, D., Easton, S., \& Kinman, G. (2009). The Work-related Quality of Life Scale for Higher Education.. Quality in Higher Education, 15(3), 207-219.

Elizur, D., \&Shye, S. (2011): Quality Of Work Life And Its Relations To Quality Of Life. Applied Psychology: An International Review, 39 (3), $275-291$.

Feuer, D. (1989). Quality of Work Life: A Cure for all Ills? Training: The Magazine of Human Resources Development, 26, 65-66.

Firestone, W., \& Rosenblum, S. (1988). Building Commitment in Urban High Schools. Educational Evaluation and Policy Analysis, 10(4), $285-299$.

Fitzsimmons, P. (2002). Teaching Reading in Paradise: A Fijian Principal Coping with Change. Reading Online, 5(8), Journal of the International Reading Association. Retrieved from www.reading online.org.

Fornell, E. F., \& Larker, D. F. (1981). Evaluating Structural Equation Models with Unobservable Variables and Measurement Error. Journal of Marketing Research, $18,39-50$.

French, J., Caplan, R., \& Van Harrison, R. (1982). The Mechanisms of Job Stress And Strain. New York: Wiley.

French, J., Rogers, W., \& Cobb, S. (1974). A Model of Person-Environment Fit, Coping and Adaptation.. New York: Basic Books Inc.

Gerstner, C. R., \& Day, D. V. (1994). Cross-Cultural Comparison of Leadership Prototypes. Leadership Quarterly, 5(2), 121-134.

Hair, J. F., Black, W. C., Babin, B. J., \& Anderson, R. E. (Eds.) (2010). Multivariate Data Analysis. (Eds.). New Jersey: Prentice Hall.

Hamidi, F. \& Mohamadi, B. (2012). Teachers' Quality of Work Life in Secondary Schools. International Journal of Vocational and Technical Education, 4(1), 1-5.

Herzberg, F. (1966). Work and the Nature of Man. Cleveland, Ohio: The World Publishing Company.

Herzberg, F., Mausner, B., \& Snyderman, B. (2010). The Motivation to Work (12th ed.). New Brunswick: Transaction Publishers.

Holt, T. (1998). Quality Work and Conflicting Quality Objectives. New York: Elsevier Science Ltd.

Hooper, D., Coughlan, J., \& Mullen, M. R. (2008). Structural Equation Modeling: Guidelines for Determining Model Fit. The Electronic Journal of Business Research Methods, 6(1), 53-60.

Hsu, M.Y., \& Kernohan, G. (2005). Dimensions of Hospital Nurses' Quality of Working Life. Journal of Advanced Nursing, 54(1), 120-131.

Hu, L., \& Bentler, P. M. (1999). Cutoff Criteria for Fit Indexes in Covariance Structure Analysis: Conventional Criteria versus New Alternative. Structural Equation Modeling, 6(1), 1-55.

Kementerian Pendidikan Malaysia (2016). Kajian Antarabangsa Pengajaran dan Pembelajaran 2013. Kementerian Pendidikan Malaysia: Bahagian Pendidikan Guru. Kotter, J. (1982). The Maturation of Career Theory. Human Relations, 35(1), 19.

Little, J. W. (1984). Norms Of Collegiality And Experimentation: Conditions For School Success. American Educational Research Journal, 19,325 - 340. 
Louis, K. (1998). Effects of Teacher Quality Work Life in Secondary Schools on Commitment and Sense of Efficacy. School Effectiveness and School Improvement, 9(1), 1-27.

Louis, K., \& Smith, B. (1990). Restructuring, Teacher Engagement and School Culture: Perspectives on School Reform and the Improvement of Teacher's Work. School Effectiveness and School Improvement, 2(1), 34-52.

MacCallum, R. C., Browne, M. W., \& Sugawara, H. M. (1996). Power Analysis and Determination of Sample Size for Covariance Structure Modeling. Psychological Methods, 1(2), 130-149.

Manju, N. D. (2014). Quality of Work Life: Perception of School Teachers. International Journal of Education and Psychological Research, 3(2), 77 - 80.

Maslow, A. H. (1954). Motivation and Personality. New York: Harper.

Mohanraj, P. \& Ramesh, R. (2010). Measuring Quality of Work Life: An Integration of Conceptual Relationship with Productivity. International Journal of Research in Management and Commerce, 1(6), 128-132.

Mohd. Hanefah, M., Md Zain, A.Y., Mat Zain, R., \& Ismail, H. (2003). Quality of Work Life and Organizational Commitment among Professionals in Malaysia Proceedings of the 1st International Conference of the Asian Academy of Applied Business: Narrowing the Competitive Gap of Emerging Markets In The Global Economy. 10-12 July 2003 Sabah, Malaysia

Morin, E. M., \& Morin, W. (2003). Quality of Work Life and Firm Performance: The Case of Teknika. Retrieved from http://www.fgvsp.

Nunnally, J. C., \& Bernstein, I. H. (1994). Psychometric theory. New York: McGraw Hill.

Pasmore, W. A (1982) Socio Technical Systems: A North American Reflection of Empirical Studies of the Seventies. Human Relations, 35, 1179 - 1204.

Phan, G. T., \& Vo, T. Q. (2016). A Literature Review on Quality of Work Life: A Case of Healthcare Workers. Journal of Applied Pharmacentical Science, 6(7), 193200.

Rohayati Abd Hamed (1999). Kualiti Kehidupan Kerja dan Kesetiaan di Kalangan Pegawai Perkhidmatan Pendidikan Sekolah-sekolah Menengah Harian di Daerah Hulu Langat. Bahan Tidak Diterbitkan, Universiti Utara Malaysia, Sintok.

Rosenholtz, S. J. (1989). Teacher Workplace: The Social Organization of School: The Social Organization of School. New York: Teacher College Press.

Rossmiller, R. (1992). The Secondary School Principal and Teachers' Quality of Work Life. Educational Management Administration \& Leadership, 20 (3), 132.

Schumacker, R. E., \& Lomax, R. G. (2004). A Beginner's Guide to Structural Equation Modelling. (2nd ed.). Mahwah, NJ: Lawrence Erlbaum Associates.

Sirgy, M. J., Efraty, D. Siegel, P., \& Lee, D-J. (2001). A New Measure of Quality of Work Life (QWL) based on Need Satisfaction and Spillover Theories. Social Indicators Research, 55, 241-302.

Spreitzer, G. M., Perttula, K. H. \& Xin, K. (2005). Traditionally Matters: An Examination of the Effectiveness of Transformational Leadership in the United States and Taiwan. Journal of Organizational Behavior, 26(3), 205-227.

Sturman, L. (2003). Survey of Quality of Working Life in Teachers. Retrieved from http://www.nfev.ac.uk/research-areas/pims-data/sum.

Taylor, J. (1978). An Empirical Examination of the Dimensions of Quality of Working Life. Omega, 6(2), 153-160.

Terborg, J. (1983). Organizational Performance and Organizational Level Training and Support. Personnel Psychology, 38(4), 849-863.

Thompson, J. (1967). Organizations in Action: Social Science Bases of Administration. New York: McGraw-Hill.

Trist, E. L. (1983). Work Life in the 1980s. In H. Kolodny \& H. Van Beinum (Eds.), The Quality of Work Life in the 1980s. (pp. 8-15). New York: Preager.

Walton, R. (1973). Quality of Life at Work: What is? Sloan Management Review, 15(1), 11-21.

Walton, R. E. (1975). Criteria for Quality of Working Life. In L. E. Davis, A. B. Cherns and Associates (Eds.). The Quality of Working Life (pp. 91-104). New York: The Free Press.

Yavari, Y., Amirtash, A. M., \& Tondnevis, F. (2009). Comparison of Quality of Work Life among Faculty Members in Physic Department. Journal Of Movement Science, 7(13), 99-109.

Yousuf, A. (1996). Evaluating the Quality of Work Life. Management and Labour Studies, 21(1), 5-15. 